\title{
Foraging Eurasian Jays (Garrulus glandarius) prefer oaks and acorns in central Europe
}

\author{
Cezary Mitrus ${ }^{1, *} \&$ Josif SzABO ${ }^{2}$
}

Received: December 14, 2019 - Revised: February 17, 2020 -Accepted: February 18, 2020

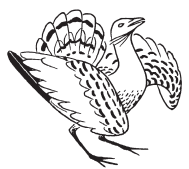

Mitrus, C. \& Szabo, J. 2020. Foraging Eurasian Jays (Garrulus glandarius) prefer oaks and acorns in central Europe. - Ornis Hungarica 28(2): 169-175. DOI: 10.2478/orhu-2020-0010

Abstract The Eurasian Jay (Garrulus glandarius) is considered as the most important factor in the dispersal and spread of oak species. We conducted studies in oak stands in four countries (Poland, Hungary, Romania, Ukraine) in the autumn of 2015 and 2016. To identify the preferences of Jays for both acorns and trees, we compared the size of acorns and tree characteristics between each selected tree and the closest unused oak. We found that acorns from selected oaks were smaller (narrower) than those from unused trees. We found no differences in the characteristics of selected and unused oaks. These results indicate that the size of acorns can be an important indicator determining the choices of foraging birds. The Jays' preferences for specific trees may influence the composition of oak populations. Trees with certain phenotypic and genomic characteristics may be favoured and dominate in the ecosystem.

Keywords: dispersion, trees, birds, preferences, coevolution

Összefoglalás A szajkó (Garrulus glandarius) a legfontosabb faktornak tekinthető a tölgyfajok terjedésében. Vizsgálatainkat négy ország (Lengyelország, Magyarország, Románia, Ukrajna) tölgyeseiben végeztük 2015 és 2016 öszén. A szajkók tölgyfa és makk preferenciáinak vizsgálatához összehasonlítottuk a szajkók által választott fák és azok makkjainak jellemzőit a legközelebbi, nem választott tölgyfával és annak makkjaival. A madarak által választott makkok kisebbek (keskenyebbek) voltak a nem választott fák makkjaihoz képest. Más vizsgált jellemzőben nem találtunk különbséget a választott és nem választott tölgyfák között. Az eredmények rámutatnak arra, hogy a makkok mérete fontos indikátor lehet a madarak táplálékválasztásában. A szajkók preferenciái kihathatnak a tölgyállományok összetételére. Bizonyos feno-, illetve genotípusú fák kedveltebbek lehetnek, így uralhatják az ökoszisztémát.

Kulcsszavak: diszperzió, fák, madarak, preferenciák, koevolúció

${ }^{1}$ Department of Vertebrate Ecology and Paleontology, Institute of Biology, Wroctaw University of Environmental and Life Sciences, Chetmońskiego 38c, 51-631 Wroctaw, Poland

${ }^{2}$ Str.Croitorilor 2/49, Odorheiu Secuiesc/Harghita 535600, România

* corresponding author

\section{Introduction}

Animals are required for dispersing the seeds of many plant species in both the tropics and in temperate zones (Howe \& Smallwood 1982, Jordano 2000). Based on the way in which seeds are transported, three categories of zoochory are usually distinguished: endozoochory - seeds are ingested by an animal and later regurgitated or defecated, epizoochory seeds are accidentally attached to the outside of an animal body, for example, in the fur, and synzoochory - animals actively transport seeds and deposit them elsewhere (Jordano 2000, Hulme 2002, Will \& Tackenberg 2008, Vander Wall \& Beck 2012). In particular, birds play an important role in plant dispersion over long distance and this is a good example of 
synzoochory. In many cases, a very close association between animals and plants can be considered as coevolution (Pons \& Pausas 2007). Mutualism, being advantageous both for birds and plants, is also observed (Pesendorfer et al. 2016). Thus, such a coexistence gives the opportunity to study relationships between birds and plants. The Eurasian Jay (Garrulus glandarius) is considered the most important factor in the dispersal and spread of oak Quercus species (Bossema 1979, Clayton et al. 1996, Perea et al. 2011, Kurek et al. 2018). Long distance dispersal of acorns is possible due to the ability of Jays to collect, carry and cache seeds in the ground (Bossema 1979, Mosandl \& Kleinert 1998, Pons \& Pausas 2007, Kurek $\&$ Dobrowolska 2016). Birds are selective and choose acorns for hoarding by visual means, mainly according to the colour and size (Bossema 1979, Pons \& Pausas 2007, Richardson et al. 2013, Bieberich 2016). However, few studies addressed the selection of acorns by Jays (Bossema 1979, Pons \& Pausas 2007, Myczko et al. 2014, Bieberich 2016) and knowledge on the characteristics of trees selected for foraging is lacking.

The aim of this study was to determine the foraging preferences of Jays in relation to the characteristics of oaks and acorns in central Europe. We tested the following hypotheses: Jays collect acorns from specific trees, oaks and acorns selected by birds differ from unused trees, location (country) does not influence the characteristics of trees and acorns.

\section{Materials and methods}

\section{Study area}

Observations were made in four countries (Poland, Hungary, Romania, Ukraine) in oak stands on lower (250-450 m above sea level) parts of the Carpathian region. In Poland, the studies were conducted in the oak forest near Kalwaria Pacławska $\left(49^{\circ} 38^{\prime} 44.5^{\prime \prime} \mathrm{N}\right.$, $\left.22^{\circ} 41^{\prime} 48.5^{\prime \prime} \mathrm{E}\right)-30$ ha, in Hungary in the Bükk National Park in the vicinity of Cserépfalu (E 47 $\left.58^{\prime} 00.0^{\prime \prime} \mathrm{N}, 20^{\circ} 33^{\prime} 47.6^{\prime \prime} \mathrm{E}\right)-20 \mathrm{ha}$, in Ukraine close to Ivanivka $\left(48^{\circ} 53^{\prime} 18.0^{\prime \prime} \mathrm{N}\right.$ $\left.24^{\circ} 06^{\prime} 03.1^{\prime \prime} \mathrm{E}\right)-30$ ha and in Romania near Homoródújfalu $\left(46^{\circ} 07^{\prime} 50.8^{\prime \prime} \mathrm{N} 25^{\circ} 24^{\prime} 56.1^{\prime \prime} \mathrm{E}\right)$ -20 ha. In the cases of Romania and Hungary, the oak stands were within pasture with the trees usually (only oaks) growing at low density. Herds of cattle and sheep grazed beneath the trees. In the case of Hungary, turkey oaks (Quercus cerris) dominated in the stands with only single individuals of pedunculate oak (Quercus robur), also present.

In Poland and Ukraine, trees in abandoned (20-30 years ago) wood-pastures had expanded to produce mixed forest, where beside stands of pedunculate oak, there were also stands of other trees: hornbeam (Carpinus betulus), beech (Fagus sylvatica), sycamore (Acer pseudoplatanus), small-leaved lime (Tilia cordata), norway spruce (Picea abies), European silver (Abies alba) and in the lower layers, common hazel (Corylus avellana).

\section{Field data collection}

The observations were carried out in two autumn seasons (2015 in Poland and Ukraine, 2016 in Hungary and Romania) in October and November. The total observation time 
amounts 42 days ( 20 days in 2015 and 22 days in 2016). Trees used by birds were located in oak stands or pastures with solitary trees by observations of flying Jays. Only oaks where foraging Jays were observed at least twice were used in the analysis. The following information was then collected: characteristics of the selected tree (species, trunk circumference at height of $1.5 \mathrm{~m}$, height of tree, radius of crown) and habitat characteristics (inside forest or in open area in the case of solitary oaks). The same characteristics were recorded for the nearest oak with acorns but not used by Jays. In the case of open areas, only unused oaks within $20 \mathrm{~m}$ were included in analysis. Additionally, the characteristics of fallen acorns under oaks were described. From the ground under each used and the closest unused oak, 50 randomly selected (without signs of infestation by insects) acorns were collected. After drying in the laboratory, they were measured using sliding callipers by one person $(\mathrm{CM})$ recording length and width (in $\mathrm{mm}$ ).

\section{Statistical analyses}

For comparisons of two groups of data the Mann-Whitney $U$ test was used. To determine factors affecting the Jay's choice, Generalized Linear Model (GLM) with binominal distribution and logit function were constructed where: biometric traits of acorns and country (place of observation) were used as independent factors. Because of the number of data, this model was used only in the case of pedunculate oaks. All statistical analyses were undertaken using Statistica for Windows v.13.3.

\section{Results}

Jays used two species of oaks: Quercus robur in the studies in Poland, Ukraine and Romania, and Q. cerris in the case of study in Hungary. In total, 421 visits of Jays were observed. We characterised 25 (5 from Ukraine, 6 from Poland, 6 from Romania and 8 from Hungary) used and 12 unused oaks ( 3 from Ukraine, 2 from Poland, 3 from Romania and 4 from Hungary). We did not find differences in the parameters (height, size of crown and diameter of trunk) of selected and unused trees (Table 1). The oaks which were used by foraging Jays in open areas were significantly shorter in height and had bigger crowns

Table 1. Characteristics of oaks selected and unused by Jays

1. táblázat A szajkók által használt és nem használt tölgyek jellemzői

\begin{tabular}{|l|c|c|c|c|c|c|c|c|c|}
\hline & \multicolumn{5}{|c|}{ Selected } & \multicolumn{5}{c|}{ Unused } & \\
\cline { 2 - 10 } & NN & Mean & Min-Max & Sd & N & Mean & Min-Max & Sd & U test, $\mathbf{p}$ \\
\hline Height (m) & 25 & 22.7 & $14-30$ & 4.81 & 12 & 24.2 & $19-31$ & 4.38 & $\begin{array}{c}-0.69, \\
p=0.49\end{array}$ \\
\hline Crown (m) & 25 & 7.8 & $4.7-12.4$ & 2.30 & 12 & 7.8 & $6.0-11.1$ & 1.32 & $\begin{array}{c}-0.42, \\
p=0,67\end{array}$ \\
\hline Circumference (cm) & 25 & 217.2 & $129-430$ & 83.10 & 12 & 216.4 & $119-345$ & 82.79 & $\begin{array}{c}0.08, \\
p=0.93\end{array}$ \\
\hline
\end{tabular}


than those growing in the forest (Table 2). Place (country) of observation and size (width but not length) influenced the selection of Jays in the case of $Q$ robur (Table 3, 4). The size of acorns also depended on oak species. Acorns of $Q$. cerris were significantly longer and wider than those from $Q$. robur (Table 5).

Table 2. Comparison of oaks growing in two different habitats

2. táblázat A tölgyfák jellemzőinek összehasonlítása nyílt és zárt állományban

\begin{tabular}{|l|c|c|c|c|c|c|c|c|c|}
\hline & \multicolumn{5}{|c|}{ Open area } & \multicolumn{5}{c|}{ Forest } & \\
\cline { 2 - 10 } & N & Mean & Min-Max & Sd & N & Mean & Min-Max & Sd & U test, $\mathbf{p}$ \\
\hline Height (m) & 25 & 18.8 & $14.0-30.0$ & 5.26 & 12 & 24.5 & $19.0-31.0$ & 3.64 & $\begin{array}{c}2.80, \\
p<0.01\end{array}$ \\
\hline Crown (m) & 25 & 8.8 & $4.7-12.0$ & 2.12 & 12 & 7.4 & $5.1-12.4$ & 1.88 & $\begin{array}{c}-1.95 \\
p<0.05\end{array}$ \\
\hline Circumference (cm) & 25 & 224.3 & $120-430$ & 82.52 & 12 & 18.75 & $119-330$ & 83.00 & $\begin{array}{c}-0.79, \\
p=0.43\end{array}$ \\
\hline
\end{tabular}

Table 3. Characteristics of acorns from selected and unused trees by Jays

3. táblázat A szajkók által használt és nem használt makkok jellemzőinek összehasonlítása

\begin{tabular}{|l|c|c|c|c|c|c|c|c|}
\hline & \multicolumn{4}{|c|}{ Selected } & \multicolumn{4}{c|}{ Unused } \\
\cline { 2 - 9 } & $\mathbf{N}$ & Mean & Min-Max & Sd & N & Mean & Min-Max & Sd \\
\hline Length $(\mathrm{mm})$ & 1235 & 25.49 & $9.7-24.4$ & 3.84 & 520 & 28.69 & $9.1-22.8$ & 2.33 \\
\hline Width $(\mathrm{m})$ & 1235 & 14.94 & $14.2-37.1$ & 1.79 & 520 & 16.10 & $16.5-39.0$ & 4.98 \\
\hline
\end{tabular}

Table 4. Results of Generalised Linear Model testing the relationships between Jays' choice and parameters of acorns and place of observation

4. táblázat Az általánosított lineáris modellek eredményei a szajkók által választott makkok hossza, szélessége és a vizsgálat országai szerint

\begin{tabular}{|l|c|c|c|}
\hline & Degrees of freedom & Wald's Statistic & P \\
\hline Length $(\mathrm{mm})$ & 1 & 8.68 & 0.003 \\
\hline Width $(\mathrm{mm})$ & 1 & 0.02 & 0.900 \\
\hline Country & 1 & 65.08 & $<0.001$ \\
\hline
\end{tabular}

Table 5. Comparison of acorns of two species of oaks

5. táblázat A szajkók által használt makkok jellemzőinek fajok közötti összehasonlítása

\begin{tabular}{|l|c|c|c|c|c|c|c|c|c|}
\hline & \multicolumn{5}{|c|}{ Q. robur } & \multicolumn{5}{c|}{ Q. cerris } & \\
\cline { 2 - 10 } & N & Mean & Min-Max & Sd & N & Mean & Min-Max & Sd & U test, $\mathbf{p}$ \\
\hline Length (mm) & 1155 & 24.79 & $14.2-37.3$ & 3.76 & 600 & 28.69 & $17.4-39.0$ & 3.96 & $\begin{array}{c}-21.63, \\
\mathbf{p}<0.01\end{array}$ \\
\hline Width (mm) & 1155 & 14.79 & $9.1-24.4$ & 1.95 & 600 & 16.10 & $11.8-24.3$ & 1.84 & $\begin{array}{c}-14.35 \\
\mathrm{P}<0.01\end{array}$ \\
\hline
\end{tabular}




\section{Discussion}

Our results indicated that the characteristics of acorns are the most important factors for foraging Jays. Birds collected acorns which were smaller than those growing on neighbouring unused trees. Earlier studies also showed experimentally that the size of acorns was an important factor for Jays collecting food (Pons \& Pausas 2007). However, these authors showed that Jays preferred bigger acorns. Preference for bigger acorns has implications for the process of oak dispersion and according to these results large acorns appear to have a higher chance of being dispersed, and in this way, an increased probability of germination and seedling establishment (Tripathi \& Khan 1990, Sonensson 1994, Bonfil 1998, Gómez 2003). Selection for bigger acorns could also lead to an increase in the size of acorns in oaks, but this evolutionary process can be limited by the physical constraints on Jays for handling, swallowing and transporting very big acorns (Pons \& Pausas 2007). This ability is related to the size of their bill and throat (Gómez 2004). Pons and Pausas (2007) suggested that the limiting size of acorns is $17.2 \mathrm{~mm}$ in width. Thus, as observed in our study, the size of acorns collected from preferred oaks are an appropriate size for Jays to swallow.

Our studies also indicated a preference by Jays for specific trees for foraging, although, the morphological characteristics of the oaks were not significant for birds whereas the size of acorns was important. Bigger acorn should be preferred by Jays because the size can be related to the nutritional content and indicates the condition of the acorn (Gómez 2004, Pons \& Pausas 2007). However, studies about acorns' chemical composition are scarce (Johnson et al. 1993, Fleck \& Woolfenden 1997, Kilic et al. 2010). Features of acorns of specific trees can differ not only in size but also in chemical composition. Łuczaj et al. (2014) indicated that acorns differ in tannin content not only between species of oaks but also between individual trees of the same species. Thus, preferences of Jays for specific trees can be related to various aspects. It may be connected not only with size of acorns but also to their nutrient characteristics. The other factor influencing Jays' choices may be related to infestation of acorns. Other studies indicated that Jays preferred undamaged acorns (Bossema 1979, Pons $\&$ Pausas 2007). The specific individual trees can differ in level of infestation by arthropods and Jays can prefer trees with a lower incidence of affected acorns. Similar to other corvids (Emery \& Clayton 2004), preferences for specific trees can be perpetuated by observation and repeated choices of other individual Jays.

Jays' selection in relation to the size of acorns and for specific trees can involve not only phenotypic characteristics of acorns but also features of the trees and as a consequence, Jays can help them to disperse their seeds. Thus, Jays' preferences can influence the composition of oak populations, trees with certain phenotypic and genomic characteristics may be favoured and become dominant in the ecosystem assuming that Jays' preferences are consistent across years. 


\section{Acknowledgements}

Financial support was received through the project 'Oak woods in rural landscapes of the Carpathian region: origin, dynamics and conservation values, financed by the National Science Centre, Poland, following the decision DEC-2013/11/B/NZ9/00793. We are grateful to Shelley Hinsley and Magda Górowska for providing comments that improved the quality of the manuscript and for correcting the English version.

\section{References}

Bieberich, J. 2016. Acorns of introduced Quercus rubra are neglected by European Jay but spread by mice. - Annals of Forest Research 59(2): 1-10. DOI: 10.15287/afr.2016.522

Bonfil, C. 1998. The effect of seed size, cotyledon reserves, and herbivory on seedling survival and growth in Quercus rugose and Q. laurina (Fagaceae). - American Journal of Botany 85(1): 79-87. DOI: 10.2307/2446557

Bossema, I. 1979. Jays and oaks: An eco-ethological study of asymbiosis. - Behaviour 70(1-2): 1-116. DOI: $10.1163 / 156853979$ X00016

Clayton, N. S., Mellor, R. \& Jackson, A. 1996. Seasonal patterns of food storing in the Jay Garrulus glandarius. - Ibis 138(4): 250-255. DOI: 10.1111/j.1474-919X.1996.tb04336.x

Emery, N. J. \& Clayton, N. S. 2004. The mentality of crows: convergent evolution of intelligence in corvids and apes. - Science 306(5703): 1903-1907. DOI: 10.1126/science.1098410.

Fleck, D. C. \& Woolfenden, G. E. 1997. Can acorn tannin predict scrub-jay caching behavior? - Journal of Chemical Ecology 23(3): 793-806.

Gómez, J. M. 2003. Spatial patterns in long-distance dispersal of Quercus ilex acorns by Jays in a heterogeneous landscape. - Ecography 26(5): 573-584. DOI: 10.1034/j.1600-0587.2003.03586.x

Gómez, J. M. 2004. Bigger is not always better: conflicting selective pressures on seed size in Quercus ilex. Evolution 58(1): 71-80. DOI: 10.1111/j.0014-3820.2004.tb01574.x

Howe, H. F. \& Smallwood, J. 1982. Ecology of seed dispersal. - Annual Review of Ecology and Systematics 13: 201-228.

Hulme, P. E. 2002. Seed-eaters: Seed dispersal, destruction and demography. - In: Levey, D. J., Silva, W. R. \& Galetti, M. (eds.) Seed Dispersal and Frugivory: Ecology, Evolution and Conservation. - CABI, Wallingford, UK, pp. 257-273.

Johnson, W. C., Thomas, L. \& Adkisson, C. S. 1993. Dietary circumvention of acorn tannins by Blue Jays. Oecologia 94: 159-164.

Jordano, P. 2000. Fruits and frugivory. - In: Fenner, M. (ed.) Seeds: The Ecology of Regeneration in Plant Communities. - CABI, Wallingford, UK, pp. 125-165.

Kurek, P. \& Dobrowolska, D. 2016. Acorns dispersal by Jays Garrulus glandarius onto clear-cuts and under the forest canopy. - Sylwan 160(6): 512-518.

Kurek, P., Dobrowolska, D., Wiatrowska, B. \& Dylewski, L. 2018. What if Eurasian Jay Garrulus glandarius would larder acorns instead of scatter them? - Forest 11(5): 685-689. DOI: 10.3832/ifor2793-011

Kilic, U., Boga, M. \& Guven, I. 2010. Chemical composition and nutritive value of oak (Quercus robur) nut and leaves. - Journal of Applied Animal Research 38(1): 101-104. DOI: 10.1080/09712119.2010.9707165

Łuczaj, Ł., Adamczak, A. \& Duda, M. 2014. Tannin content in acorns (Quercus spp.) from Poland. - Dendrobiology 72: 103-111. DOI: 10.12657/denbio.072.009

Mosandl, R. \& Kleinert, A. 1998. Development of oaks (Quercus petraea (Matt.) Liebl.) emerged from bird-dispersed seeds under old-growth pine (Pinus silvestris L.) stands. - Forest Ecology and Management 106(1): 35-44. DOI: 10.1016/S0378-1127(97)00237-5

Myczko, Ł., Dylewski, Ł., Zduniak, P., Sparks, T. H. \& Tryjanowski, P. 2014. Predation and dispersal of acorns by European Jay (Garrulus glandarius) differs between a native (pedunculate oak Quercus robur) and an introduced oak species (northern red oak Quercus rubra) in Europe. - Forest Ecology and Management 331: 35-39. DOI: 10.1016/j.foreco.2014.07.027

Perea, R., San Miguel, A. \& Gil, L. 2011. Flying vs. climbing: Factors controlling arboreal seed removal in oakbeech forests. - Forest Ecology and Management 262(7): 1251-257. DOI: 10.1016/j.foreco.2011.06.022 
Pesendorfer, M. B., Sillett, T. S., Koenig, W. D. \& Morrison, S. A. 2016. Scatter-hoarding corvids as seed dispersers for oaks and pines: a review on a widely distributed mutualism and its utility to habitat restoration. - The Condor 118(2): 215-237. DOI: 10.1650/CONDOR-15-125.1

Pons, J. \& Pausas, J. G. 2007. Not only size matters: acorn selection by the European Jay (Garrulus glandarius). - Acta Oecologica 31(3): 353-360. DOI: 10.1016/j.actao.2007.01.004

Richardson, K. B., Lichti, N. I. \& Swihart, R. K. 2013. Acorn-foraging preferences of four species of free-ranging avian seed predators in eastern deciduous forests. - The Condor 115(4): 863-873. DOI: 10.1525/ cond.2013.120189

Sonensson, L. K. 1994. Growth and survival after cotyledon removal in Quercus robur seedlings, grown in different natural soil types. - Oikos 69(1): 65-70. DOI: 10.2307/3545284

Tripathi, R. S. \& Khan, M. L. 1990. Effects of seed weight and microsite characteristics on germination and seedling fitness in two species of Quercus in a subtropical wet hill forest. - Oikos 57(3): 289-296. DOI: $10.2307 / 3565956$

Vander Wall, S. \& Beck, M. J. 2012. A comparison of frugivory and scatter-hoarding seed-dispersal syndromes. Botanical Review 78: 10-31. DOI: 10.1007/s12229-011-9093-9

Will, H. \& Tackenberg, O. 2008. A mechanistic simulation model of seed dispersal by animals. - Journal of Ecology 96(5): 1011-1022. DOI: 10.1111/j.1365-2745.2007.01341.x

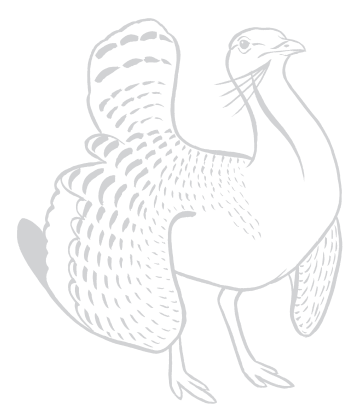

